AperTO - Archivio Istituzionale Open Access dell'Università di Torino

\title{
Information and Financial Literacy for Socially Sustainable NDC Pension Schemes
}

\section{This is the author's manuscript}

Original Citation:

Availability:

This version is available http://hdl.handle.net/2318/1767978

since 2021-12-18T18:10:51Z

Publisher:

World Bank Publications

Published version:

DOI:10.1596/978-1-4648-1455-6_ch25

Terms of use:

Open Access

Anyone can freely access the full text of works made available as "Open Access". Works made available under a Creative Commons license can be used according to the terms and conditions of said license. Use of all other works requires consent of the right holder (author or publisher) if not exempted from copyright protection by the applicable law. 


\title{
SOCIAL PROTECTION \& JOBS \\ DISCUSSION PAPER
}

No. $1924 \mid$ April 2019

\section{Information and Financial Literacy for Socially Sustainable NDC Pension Schemes}

\author{
Elsa Fornero, Noemi Oggero, \\ and Riccardo Puglisi
}


(C) 2019 International Bank for Reconstruction and Development / The World Bank

\section{H Street NW}

Washington DC 20433

Telephone: +1 (202) 4731000

Internet: www.worldbank.org

This work is a product of the staff of The World Bank with external contributions. The findings, interpretations, and conclusions expressed in this work do not necessarily reflect the views of The World Bank, its Board of Executive Directors, or the governments they represent.

The World Bank does not guarantee the accuracy of the data included in this work. The boundaries, colors, denominations, and other information shown on any map in this work do not imply any judgment on the part of The World Bank concerning the legal status of any territory or the endorsement or acceptance of such boundaries.

\section{RIGHTS AND PERMISSIONS}

The material in this work is subject to copyright. Because The World Bank encourages dissemination of its knowledge, this work may be reproduced, in whole or in part, for noncommercial purposes as long as full attribution to this work is given.

Any queries on rights and licenses, including subsidiary rights, should be addressed to World Bank Publications, The World Bank Group, 1818 H Street NW, Washington, DC 20433, USA; fax: +1 (202) 522 2625; e-mail: pubrights@worldbank.org. 


\begin{abstract}
This paper is centered on the complementary roles played by pension communication/information and financial literacy for a sustainable and equitable nonfinancial defined contribution (NDC) system at both the micro and macro socioeconomic level. The paper presents new evidence on: (i) the concern of public opinion about pensions in five European countries (France, Germany, Italy, Sweden, and the United Kingdom), as approximated by Google Trends data; (ii) the relationship between measures of online search volume and coverage by traditional media (i.e., national newspapers); and (iii) the volume and framing of newspaper coverage for a specific reform (i.e., the 2011 Italian reform). On the demand (users) side, the paper considers pension literacy as an element to increase the effectiveness of reforms.
\end{abstract}

Key words: Pensions, Financial Literacy, Media

JEL codes: H55, D72, J26 


\section{Acknowledgments}

This paper is written for Progress and Challenges of Nonfinancial Defined Contribution Pension Schemes, Volume 2: Addressing Gender, Administration, and Communication, edited by Robert Holzmann, Edward Palmer, Robert Palacios, and Stefano Sacchi, to be published by the World Bank in autumn 2019. We are grateful to Amy Gautam for first-rate copy editing. A first version of the paper was presented at the NDC III conference in Rome, October 5-6, 2017, and we are thankful to the participants for their comments and encouragement. The views expressed herein are those of the authors and do not necessarily reflect the views of the institutions they are associated with or the views of the World Bank. 


\section{Abbreviations and Acronyms}

$\begin{array}{ll}\text { DB } & \text { Defined Benefit } \\ \text { DC } & \text { Defined Contribution } \\ \text { GDP } & \text { Gross Domestic Product } \\ \text { NDC } & \text { Nonfinancial Defined Contribution } \\ \text { PAYG } & \text { Pay-As-You-Go }\end{array}$




\section{Table of Contents}

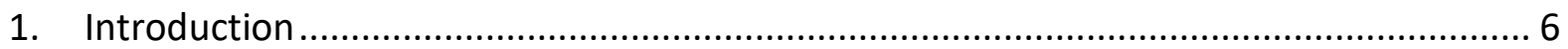

2. Pension information: Why? What? When? From whom? ......................................... 8

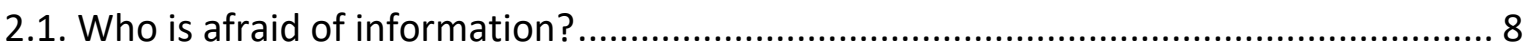

2.2. Formal information (from the pension agency) and informal information (from the

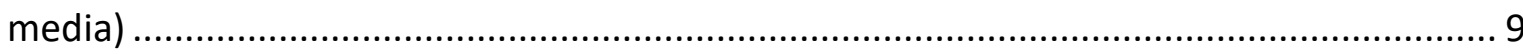

2.3. What workers should know about their own pension and retirement options ......... 11

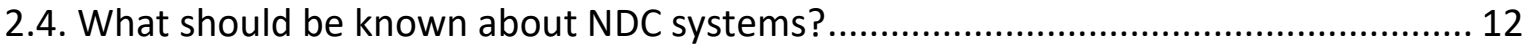

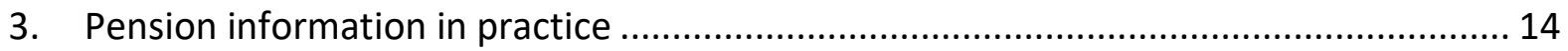

3.1. Information through public pension statements: A selective survey ...................... 14

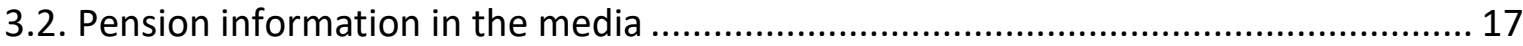

4. Financial literacy applied to pensions: What is "pension literacy"? Why is it important? 31

4.1. Why financial literacy is important for retirement: A selective review of the literature

4.2. Basic understanding of NDC pensions as insurance that can accommodate

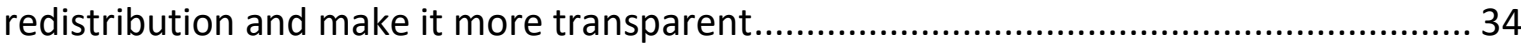

4.3. Pension literacy and the sustainability of pension systems/reforms ....................... 36

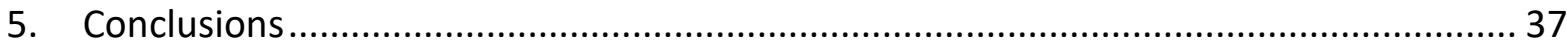

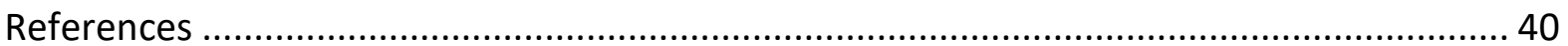




\section{Introduction}

The accumulation of pension wealth is a long and complex endeavor, with various circumstances in which individuals have to make consequential decisions, even in public systems with a strong compulsory component. Awareness is essential to increase welfare, as conscious citizens are more likely to make sensible choices and avoid regrettable mistakes. Awareness requires both information and the ability to use it wisely; this in turn requires a minimum of economic and financial knowledge, typically called financial literacy. Workers should have some knowledge (conjecture) and a basic understanding of where they stand on their accumulated (prospective) pension wealth and retirement options. This knowledge was less important in the traditional world of defined benefit (DB) pension systems, because of their more "guaranteed" nature. It is definitely essential in the case of defined contribution (DC) schemes because of their results-oriented structure, which entails more risks and a higher level of individual responsibility for both the private and public components of the pension system. This paper concentrates on the latter, and more specifically on systems that are run on a notional or pay-as-you-go (PAYG) basis and are characterized by a DC-type formula to calculate benefits (NDC systems, for brevity). ${ }^{1}$

This new pension landscape implies more, and more complex personal choices, and greater risk (although one should not forget that in the "old" DB landscape, the political risk of unsustainable promises - a risk that people are more likely to ignore by appealing to the notion of "acquired rights" - was rarely taken into account in an explicit way and even less covered). This naturally raises concerns about the amount (and quality) of information provided to citizens, as well as about citizens' level of knowledge, which affects the ability to deal with crucial financial decisions, such as planning for retirement and managing

\footnotetext{
${ }^{1}$ More specifically, the word "nonfinancial" or "notional" is used to denote a pension system that does not rely on the accumulation of funds (reserves) to pay for pensions, but on current workers' contributions that are used to pay for current retirees' benefits. The term is thus a synonym for a PAYG system. Unfunded pension systems are in general public as it is harder and certainly riskier -particularly in the case of a single profession or even a firm- to maintain the capacity "to tax" future workers to finance the benefits of current ones.
} 
savings for old age. It also raises the question of how to attain a universal minimum level of financial knowledge.

This paper investigates the importance of both information and financial literacy, as they both contribute by adding social sustainability to the inherent tendency of NDC pension systems toward financial equilibrium. ${ }^{2}$ It provides a new dimension to this discussion by exploring the role of the media in the approval and implementation of pension reforms in general and in the specific case of NDC schemes. Section 2 deals with the scope, content, and importance of information - and sometimes its lack of popularity among politicians, particularly in the case of retrenching reforms. More specifically, it distinguishes between formal and informal communication, the first officially supplied by the institutions in charge of pension provision, and the second by the media. Section 3 explores the supply side of information (i.e., the role of the media in pension knowledge and in the reform debate) by analyzing the dissemination role by both the Internet and newspapers in selected European countries, with a focus on Italy in the critical context of its 2011 pension reform. Section 4 deals with the demand (users) side: it highlights the notion of pension literacy as a specific component of financial basic knowledge and as an ingredient to "make sense" of pension information, to improve both personal decisions and the effectiveness of pension systems and reforms. Section 5 draws some (preliminary) findings as well as policy implications and outlines the main areas for future work.

\footnotetext{
2 While the NDC system can fix the financial problems created by aging and by a structural decline in productivity growth, social sustainability relates to: (i) whether pensions in the future will be sufficient to provide adequate living conditions for older people; and (ii) people's understanding and involvement. This kind of sustainability depends essentially on the good performance of the labor market and on social protection to cover the unlucky by resorting to general taxation. While today the majority of pensioners in rich countries enjoy more or less the same standard of living of the average population, the future looks bleaker for young and future generations given their greater difficulties on the labor market.
} 


\section{Pension information: Why? What? When? From whom?}

\subsection{Who is afraid of information?}

Information is critical for individual lifecycle decisions, in deciding, for example: whether to spend more or less, now or later (i.e., to save, to dissave, or not to save); to participate in a supplementary pension plan; when to retire; and whether to leave on a gradual retirement option, when available. Knowledge should help workers to better plan their retirement, thus avoiding (major) mistakes and consequent disappointments, such as a shortfall of actual versus expected pension benefits, and painful lifestyle adjustments.

Information on the functioning of unfunded pension systems - and of NDC systems as a subset thereof - is also fundamental for systems' sustainability, and thus for the political consistency of reforms. In turn, reforms are required either to adapt the pension design to economic and demographic structural changes or to improve a previous poor design, which might be due to the interference of politicians, whose electoral purposes often tend to prevail over the system's main role of providing income security in old age. Differently from individual-level choices, citizens (i.e., public opinion and voters) should also be properly informed about the aggregate behavior of the pension system. From this point of view, widespread misinterpretation of pension reforms will lead to attempts to prevent or reverse them after their approval. The reluctance of governments, politicians, and other political/social actors to provide information for fear of generating resentment and losing consensus (or even for the interest in exploiting ignorance) has to be recognized and overcome, possibly with the aid of international institutions, which typically do not share the same fears and are not constrained by short-term electoral interests.

Concerns by politicians are well expressed by the oft-quoted Juncker's aphorism: "We all know what to do, but we don't know how to get re-elected once we have done it" (The Economist, 2007; see also Buti et al. 2008). This statement implicitly stresses the importance of financial literacy: if politicians and experts are able to see the necessity, and thus the embedded social values, of reforms, why should citizens not do the same? And if 
they do, why should they punish the governments/political parties that approved the reforms $?^{3}$ If people understand the need for a reform they will not necessarily vote out a politician who takes painful steps in the short run to consolidate the system in the medium to long run. This view thus provides another reason, on top of the effects on individual planning and decisions, to champion financial literacy - it also supports an important policy action: governments could indirectly generate long-term support for more effective citizenship and virtuous reforms by promoting, together with basic financial education in schools, good information and specific financial education programs for adults. ${ }^{4}$

\subsection{Formal information (from the pension agency) and informal information (from the media)}

Information (online, written, and/or broadcast) has to be simple and trustworthy. Within a public pension system, it is obvious that it should be provided by the public pension agency, which is obliged by its mandate to provide formal, precise, and micro personalized information. This crucial informative task cannot be delegated to noninstitutional actors or private entities such as trade unions, workers' associations, and nonprofit organizations, although they can support, and typically do, the public pension institute. The importance of this kind of information, however, is not universally recognized, sometimes because of bureaucratic/political negligence, sometimes because of administrative deficiencies, and sometimes because of fear of losing electoral support, particularly in the case of reforms that try to restore the system's financial sustainability. As a consequence, not all countries have credible institutions capable and willing not only to inform members about their specific (current and prospective) personal situation, but also to produce periodic and reliable information about the financial status of the scheme. ${ }^{5}$ When this does not happen, a negative impact on views about the retirement system and its reforms is likely to occur, in

\footnotetext{
${ }^{3}$ Fornero and Lo Prete (2019) test this hypothesis by looking at the pension reforms in 21 advanced countries over 20 years, from 1990 to 2010. The study shows that while the probability of being reelected following a pension reform normally decreases, it falls less in countries with higher financial literacy scores.

4 See section 5 .

5 Sweden, the United States, and Japan are generally considered good benchmarks.
} 
turn affecting decisions as well. Of course, the provision of reliable information does not guarantee per se that it will be used correctly and wisely: sometimes formal information is simply ignored either because it is too complex and thus not understood, or because people have misperceptions about the institution providing it.

One important problem is the need to distinguish, in each worker's specific position, what has already been accumulated (like the "accrued-as-of-today" notional capital) with respect to what can reasonably be estimated for the future (and possibly for the far future) under specific hypotheses. Even if the accrued pension wealth - in the case of notional accounts, is not backed by reserves - is nothing more than a "promise" that can be changed by a political decision (normally without the need of a constitutional law), simulations of future wealth and of the implied pension benefit are, of course, much more uncertain. Hence, it is important that the difference is made transparent and understood. The first type of information is perceived as more objective; the second as more "speculative" (something like “your future pension benefit in this specific 'scenario,' including the time profile of your future contribution and a given retirement age"). Although fundamental for a proper understanding, the distinction is not easily grasped, also because the state can always "tax," either directly or indirectly through cutbacks, the accrued pension wealth and/or amend the rules for its future accumulation.

General information, particularly about the pension system's characteristics, problems, updates, innovations, and policy proposals, is provided by the media. Pensions and pension reforms are very popular topics, as all individuals are involved, either directly or indirectly (e.g., as spouses/partners or dependent children). The incentives of mass media in disseminating basic pension knowledge are likely to be quite different from those of the official pension institution, which in principle should be more neutral, but in practice might be sensitive to the government's requirements. It is still unclear whether individual opinions about pensions are more influenced by the media or by the official pension provider, a question that can depend, among other things, on the institute's public reputation. One can easily argue that the latter has a comparative advantage in providing personalized 
information about accrued capital, returns, and the like. However, the relative novelty of NDC systems - and of regulations imposing informative tasks on them - could imply that citizens still rely more heavily on information provided by better-known media, both traditional ones (newspapers, magazines, radio, and TV, particularly talk shows) and, increasingly, new ones (social networks).

\subsection{What workers should know about their own pension and retirement options}

Precise information on future pension benefits can be given only to those somewhat close to retirement, and thus with a high degree of certainty about their pension level. For the others the pension statement should clearly refer to "projections," "simulations," or "estimates," none of which is an easy term. The probabilistic nature of more distant benefits should always be emphasized, to avoid the idea that precise calculations imply the promise of a "sure amount."

On a personal level, it is therefore important that citizens are informed on:

- The (notional) accrued capital, i.e., the present value of pension wealth.

- How much of this wealth is due to: own contributions (i.e., both the employee and the employer's share), credited contributions (financed by general taxation for periods of education, unemployment, and care activities), and returns (typically calculated by using the rate of growth of the total wage bill or gross domestic product (GDP)).

- How the notional amount is transformed into a pension benefit (the conversion factor used to convert the capital into an annuity).

- Whether this transformation takes into account the (cohort-averaged) expected longevity at retirement.

- Possible retirement ages, together with a description of how the pension benefit will evolve in case of deferral, highlighting the incentives to the continuation of work or at least the absence of disincentives - that are typical of the DC method; in particular, people should know that postponing retirement contributes twice to the 
increase of individual benefits: through higher contributions and lower expected longevity (when longevity is taken into account).

- How the pension benefit will evolve in retirement (the indexation rule).

- Supplementary benefits, such as survivors' pensions and the possibility to draw on accumulated pension wealth, particularly when they are optional and not included in the default options. ${ }^{6}$

- For those whose career has developed - at least partially because of a transition toward the NDC regime - under a DB scheme, the gap between (actualized) pension benefits and accrued capital through paid contributions. The purpose of this is to give a measure of the "gift" implied by the DB scheme and to contrast people's perception of having (more than) what they "paid" for their own pension, even when this is largely untrue.

\subsection{What should be known about NDC systems?}

An NDC pension system is a complex structure that does not lend itself to straightforward interpretation. It is not a market mechanism but a public institution, which means that even when it mimics the market - as the NDC scheme does - it necessarily performs roles that the market does not or cannot perform, the first being social cohesion. In particular - even when it is largely based on insurance principles- it cannot be exempt from performing some redistribution tasks. It is very important that people are informed, even at a very basic level, about the nature of this institution, particularly its "social compact" features, which the (notional) personal accounts somehow tend to conceal. More specifically, workers should be informed that:

- A PAYG system (whether DB or DC) is an "intergenerational contract": retirees receive their pensions because of contributions paid by current workers, who

\footnotetext{
${ }^{6}$ As in the Italian case of an "Advance on Pension" (APE, "Anticipo Pensionistico," introduced in 2015), which comes in two versions: "social," when the costs are socialized, i.e., covered by general taxation, and "voluntary," when the person has to repay the debt, including the (subsidized) interest.
} 
contribute under the assumption that future generations will also pay and thus, indirectly, finance their own pensions; in the contract, the state is also supposed to represent the interest of future generations, which obviously cannot participate directly in the deal.

- When combined with a DC formula, the system (NDC) can achieve both financial equilibrium (notwithstanding its implicit debt dimension, stemming from its very creation) and greater intragenerational fairness than a "pure" DB formula. ${ }^{7}$

- The adequacy of benefits (i.e., their capability to provide financial security in old age) depends mainly on the individual's whole contributory history, thus a good working career, and on adequate tax rates.

- Contributions are credited, even if partially, for unemployment spells or work leaves due to care activities, to avoid gaps in the accumulation process.

- Returns are credited to contributions, which are a form of (compulsory) saving, not a pure tax.

- To make the social contract sustainable, and thus to protect future generations, the rate of return that is recognized must mirror the growth in the contributory base. In turn, this is approximated by the rate of growth of GDP $(\sim n+g$, the sum of population and productivity growth rates). The notion that returns are not determined by financial markets but by the rate of growth of labor income (or of the economy) should also be transparent. ${ }^{8}$ As people often seem to be rather impatient with a notion of financial equilibrium, the amount of intergenerational fairness that

\footnotetext{
7 Provided mortality rates do not differ substantially by social class. When this is not the case, corrections to the pure DC formula should be adopted.

8 Interestingly, according to an Italian survey, individuals showed an adequate knowledge of the GDP growth in 2016 resulting in an average estimated value of 0.6 percent compared to 0.8 percent registered by Istat. On the other hand, average estimated values for unemployment and inflation rates were significantly above official data (Istat 2016).
} 
is implied by using this rate of return on contributions should help in making the system less abstract and friendlier. ${ }^{9}$

- The system contains "automatic stabilizers" that encourage people to work longer as longevity increases: (i) for any given pension wealth, the benefit increases with retirement age (normally up to a maximum); and (ii) when longevity increases, the coefficients that transform the (notional) capital into a pension are normally reduced for any permissible retirement age.

All this information is not easily conveyed; even when it is, its reading is complex and certainly hardly stimulating. Nevertheless, information is essential to enhance one of the main features of the NDC system (i.e., its transparency), and to help contrast privileges and other forms of perverse redistribution. To strengthen this mission, it is important that this information is officially provided by the pension institute in an independent way.

\section{Pension information in practice}

\subsection{Information through public pension statements: A selective survey}

Since public pension programs provide the foundation for retirement income for a vast majority of workers (if not all of them), it is important for governments to give individuals detailed information about their public retirement benefits. Public pension statements are one way governments can provide workers with information about their retirement duties, rights, and options. The following looks especially at countries that have adopted an NDC system (without considering the entire list).

In Sweden, which launched its NDC system in 1998 and fully implemented it in early 2003, a substantial amount of pension and financial information is systematically and regularly provided to the population at large. The famous "Orange Envelope" has been a forerunner

\footnotetext{
${ }^{9}$ On the other hand, a long-run financial equilibrium implies that the "implicit" pension debt is matched by the system's "assets"; i.e., the present value of future contributions (plus any other financial asset).
} 
and a benchmark. It is sent by the pension institute once a year and contains individual information about previous years' contributions, personal account balances at the beginning and end of the year, annual returns, plus individual-specific projections translating the account balances into an expected monthly pension benefit calculated at three different retirement ages (Almenberg and Säve-Söderbergh 2011). It is important to notice that the projections are calculated for two assumptions about the real wage growth rate: 0 percent and 2 percent. The Envelope also contains information on the direct relationship between the annuity and the retirement age, consistent with the view of a pension as insurance against the risk of longevity. The widespread dissemination of information is likely to have lowered the barriers to planning for retirement.

As a supplement to the NDC pillar, which provides contributions-related benefits that represent the largest share of retirement income, the Swedish system also includes a funded part. Consequently, information about the functioning of financial markets is also provided, in particular with reference to the relative risks of equities versus bonds, and the inappropriateness of having a high exposure to equities close to retirement. This can be expected to have raised awareness of basic financial concepts (Almenberg and SäveSöderbergh 2011). For example, Swedish adults show a good understanding of the risk diversification concept: more than two-thirds (68 percent) of them correctly answered the risk question designed by Lusardi and Mitchell to test basic financial literacy (2008). On the other hand, it can also be the case that not everybody opens the Orange Envelope; even when they do, this is no guarantee that they can adequately absorb and understand the information. Even though most recipients claim to read the information in the Orange Envelope, less than one-half of the sample population reported to have a good understanding of the pension system, and many individuals reported that they lack sufficient knowledge to manage their individual accounts (Sundén 2009).

A comparison with Italy is instructive. Italy introduced its NDC system in 1996 but the phase-in process was so long and the general information to the people so limited (and not infrequently biased) that it took 20 years to introduce the Italian version of the Orange 
Envelope. It is thus not surprising that the new formula and even the PAYG method of financing are not yet properly understood by the population. Paradoxically, while pensions have always occupied a wide space in the news, very little has been done to explain in an official way the advantages and limitations of the new method of calculating benefits.

Similarly to Sweden, the United States' Social Security Administration is required by law to send out the Social Security Statement; i.e., the public pension statement. Even though the United States does not have an NDC pension system, legislation specifies that the statement must contain the worker's earnings history; the Social Security taxes paid by the worker; an estimate of potential retirement benefits at different retirement ages; and estimates of disability, survivors', and other auxiliary benefits. In 2000, a paragraph was added about the advantages and disadvantages of retiring early. Many studies found a significant increase in the number of respondents who knew: (i) about the relationship between Social Security benefits and earnings; (ii) how benefits are financed; (iii) that benefits increase automatically as the cost of living rises; and (iv) that the full retirement age is increasing. Moreover, respondents who reported receiving, and who had thus presumably looked at/read the statement, were more knowledgeable about the program than those who did not (Kritzer and Smith 2016). A sizable percentage of respondents also reported using the statement for financial planning, thought the information in the statement was useful for retirement planning, and expressed overall satisfaction with the information about savings and investment. However, more than one-half of workers did not believe that Social Security benefits would exist when they reach retirement age (Gallup 2015). While Mastrobuoni (2011) found that Social Security Statements had a significant impact on workers' knowledge about their benefits, he also suggested that workers did not change their retirement behavior. In particular, they did not change their expected age of retirement after receiving the statement, and their monthly claiming patterns did not show any change after introduction of the Social Security Statement.

Likewise, Canada has a legislative requirement to send workers a statement of contributions on request. For recipients aged 30 or older, the statement includes 
information on their contributions, pensionable earnings, retirement pension, and disability and survivors' benefits. For recipients younger than 30, the statement only includes information on their contributions and pensionable earnings, omitting information on the retirement pension and disability and survivors' benefits. Surveys found that more than two-thirds of respondents said the information was important to them, they had a better understanding of the Canadian pension plan and the services it provides, and they were more likely to plan for their retirement (Kritzer and Smith 2016).

In Poland, the launch of the NDC pension formula in 1996 altered the incentives for future pensioners, since postponing retirement now leads to significantly higher pension levels. However, incentives to work longer only function if society is provided with information about the pension system (Chlon-Dominczak 2009). A systematic public education effort is required to improve the "pension literacy" of the population, and a step taken by Poland in this direction is the annual information on individual accounts that the social insurance institution sends to covered workers. From 2008, this information also includes the calculation of the accrued pension based on the current account value, and the projected account value for selected potential retirement ages (Chlon-Dominczak 2009). In Latvia as well, the State Social Insurance Agency as of 1997 took initiatives aimed at improving public understanding and promoting acceptance of the NDC pension system. Media campaigns were undertaken, and contribution statements sent to contributors once a year, with an explanation of the system (Fox and Palmer 1999).

Even this brief analysis of these cases leads to the conclusion that pension information is critical for individual knowledge and planning in many areas, while both low literacy and lack of information affect the ability to secure a comfortable retirement.

\subsection{Pension information in the media}

How much information about pension systems and reforms can be found in the media, as compared to other personally and/or politically relevant issues? Do articles and editorials simply report the facts and the political contests surrounding pension reforms, or do they 
also deliver basic concepts as a precondition to understanding the mechanics and main implications of PAYG systems and DC formulae? To the authors' knowledge, these empirical research questions have not been explicitly tackled yet. The three following analyses try to answer them:

- Attention to online media: For a sample of European countries (France, Germany, Italy, Sweden, and the United Kingdom), Google Trends is used to measure the relative amount of online searches about pensions and compare them across countries and over time.

- Volume of coverage by traditional media: For the same sample of countries, the dynamics of newspaper coverage of pensions and pension reforms in the last 15 years are examined by exploiting the Dow Jones Factiva news archive.

- Type of coverage for a specific pension reform: To check the type of coverage devoted to pension reforms, the focus is turned on Italy, looking at the amount and type of newspaper coverage devoted to the last major pension reform (i.e., the Monti-Fornero reform), introduced in December 2011 in an emergency situation, very close to a financial crisis (Fornero 2014). ${ }^{10}$ More specifically, the analysis investigates how the treatment of pensions differed across newspapers and changed before and after the "natural experiment" of the reform itself.

- Regarding the first type of analysis, Error! Reference source not found.Figure 3.1 shows the relative importance of pension information in France, Germany, Italy, Sweden, and the United Kingdom from 2004 to 2017, as proxied by the Google Trends data regarding the volume of online searches. Italy and France show the highest rates of online searches regarding pensions, with Italy having the maximum number of searches at the beginning of 2015. On the other hand, Germany, Sweden, and the United Kingdom - countries that have already "sorted out" their reforms -

\footnotetext{
10 Decree-Law 201/2011, issued on December 6, 2011 (the so-called "Decreto Salva Italia") and then converted into Law 214/2011.
} 
showed less interest in pension themes in recent years. More frequent online searches by Italians and the French may indicate higher sensibility toward social security issues in these countries. While searches in France were quite steady from 2004 to 2017, Italy shows two peaks: one at the end of 2011-beginning of 2012, when the Monti-Fornero pension reform was introduced; and the other at the beginning of 2015, when the Constitutional Court's decisions on price adjustment of pensions affected many retirees. ${ }^{11}$ Thus searches were especially high when changes in the retirement landscape happened, and people probably tried to gather more information on the Internet.

Figure 3.2, Figure 3.3, Figure 3.4, Figure 3.5, and Figure 3.6 compare the volume of online searches on pensions with the volume of searches on other policy-relevant issues, for each sampled country. Figure 3.2 and Figure 3.4 confirm that social security is a hot topic in both France and Italy: from 2004 to 2017, people looked for more information on pensions than on unemployment, immigrants, crime, or ISIS. In Sweden as well, where the NDC pension system was introduced in 1998, the volume of online searches over time was larger for pensions than for other relevant topics (Figure 3.5). ${ }^{12}$

The second research question investigates how online searches regarding pensions compare to the coverage devoted to this topic by traditional media outlets over time. The availability of easily searchable news archives allows to gather monthly coverage data on selected newspapers for the countries under consideration. Data were gathered for the 2004-2017 period for Le Monde in France, Frankfurter Allgemeine Zeitung (FAZ) in Germany, Corriere della Sera in Italy, Svenska Dagbladet in Sweden, and The Times in the United Kingdom. Figure 3.7, Figure 3.8, Figure 3.9, Figure 3.10, and Figure 3.11 show for

\footnotetext{
11 In March 2015, the Italian Constitutional Court declared unconstitutional the freeze of price indexation for pension benefits higher than three times the minimum (i.e., approximately higher than $€ 1,500$ ), which had been one measure of the 2011 pension reform. As a result, the price indexation of pensions for a large number of retirees had to be resumed.

12 Unfortunately, Google Trends does not allow to check the extent to which those searches landed Internet users on the pension organization's official website or on specific news sites.
} 
each country the time series of online search volume on pensions together with the monthly count of stories ${ }^{13}$ where the word "pension" appears in the selected newspapers. The graphs show a very close correlation between online searches and newspaper coverage of the pension theme. If anything, newspaper coverage appears to be generally leading online searches. A plausible rationale for this is that citizens initially get informed from traditional media outlets and then may be induced to search for additional information on the Internet. This positive correlation is confirmed by multivariate regression analysis.

The third research question on content analysis analyzes the case of Italy, with a specific focus on enactment of the Monti-Fornero reform at the end of 2011, and on its media coverage in four national newspapers. More precisely, exploiting the Dow Jones Factiva archive, the texts of all articles in four national dailies (Corriere della Sera, Repubblica, Stampa, and Giornale) that mention anywhere the word "pensioni" (pensions) were obtained for a four-month timespan starting in November 2011 and ending in February 2012. Overall, 2,045 articles were published during the time period under consideration, split as follows: 621 articles in Corriere, 604 in Repubblica, 424 in Stampa, and 396 in Giornale. Figure 3.12 shows the histogram of articles on a daily basis in all four newspapers: there is a clear increase in coverage of pensions that rapidly reaches a maximum on December 5, i.e., the day before enactment of the Decree-Law by the newly established Monti cabinet. Then the coverage slowly drops in December (with a further spike on December 23, when the Decree-Law was converted into law), and more rapidly so in 2012, when the government was engaged in preparing the labor market reform (Fornero 2013). The topic, however, became a preferred subject for heated TV talk shows.

\footnotetext{
13 Relative to the average number of monthly articles.
} 
Figure 3.1: Google Trends, online searches of pensions in France, Germany, Italy, United Kingdom, and Sweden, 2004-2017

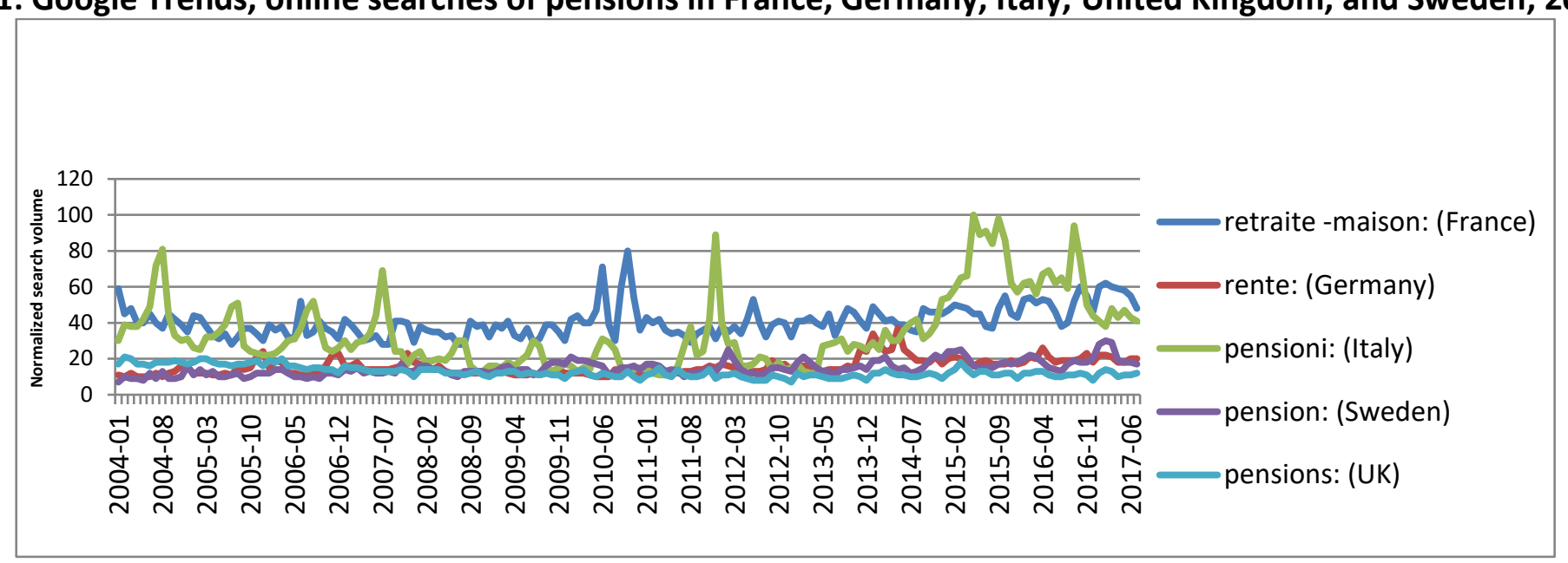

Figure 3.2: Google Trends, searches of Daesh (ISIS), immigrants, crime, unemployment, and pensions in France, 2004-2017

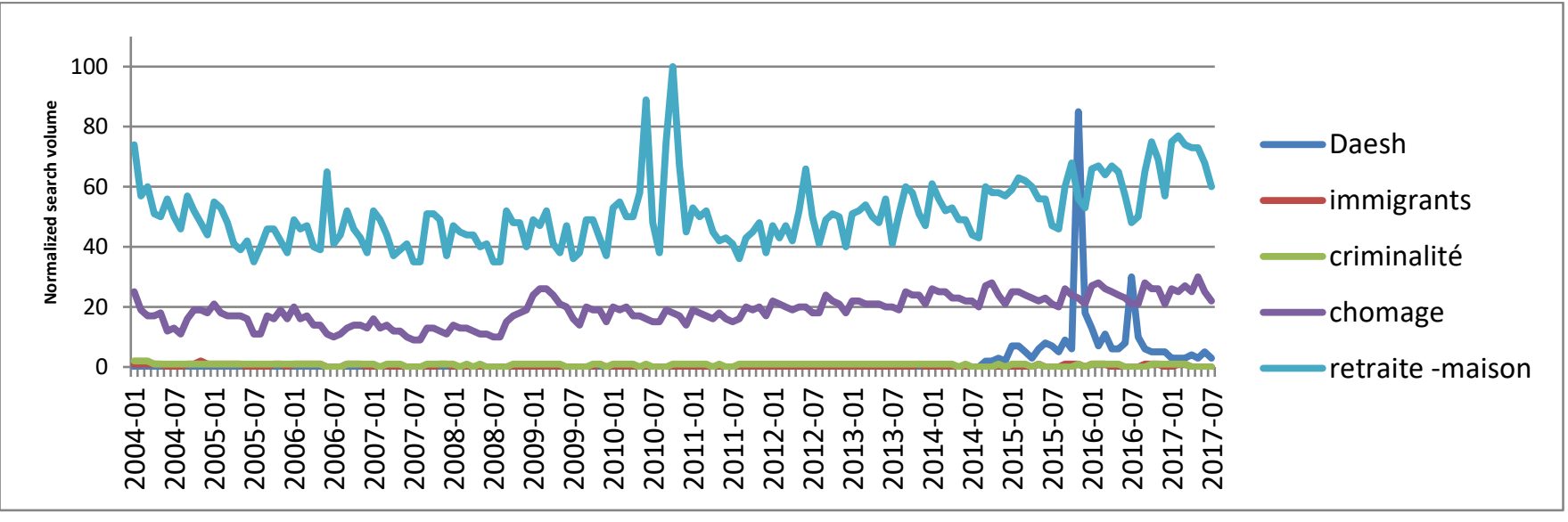


Figure 3.3: Google Trends, searches of Daesh (ISIS), refugees, crime, unemployment, and pensions in Germany, 2004-2017

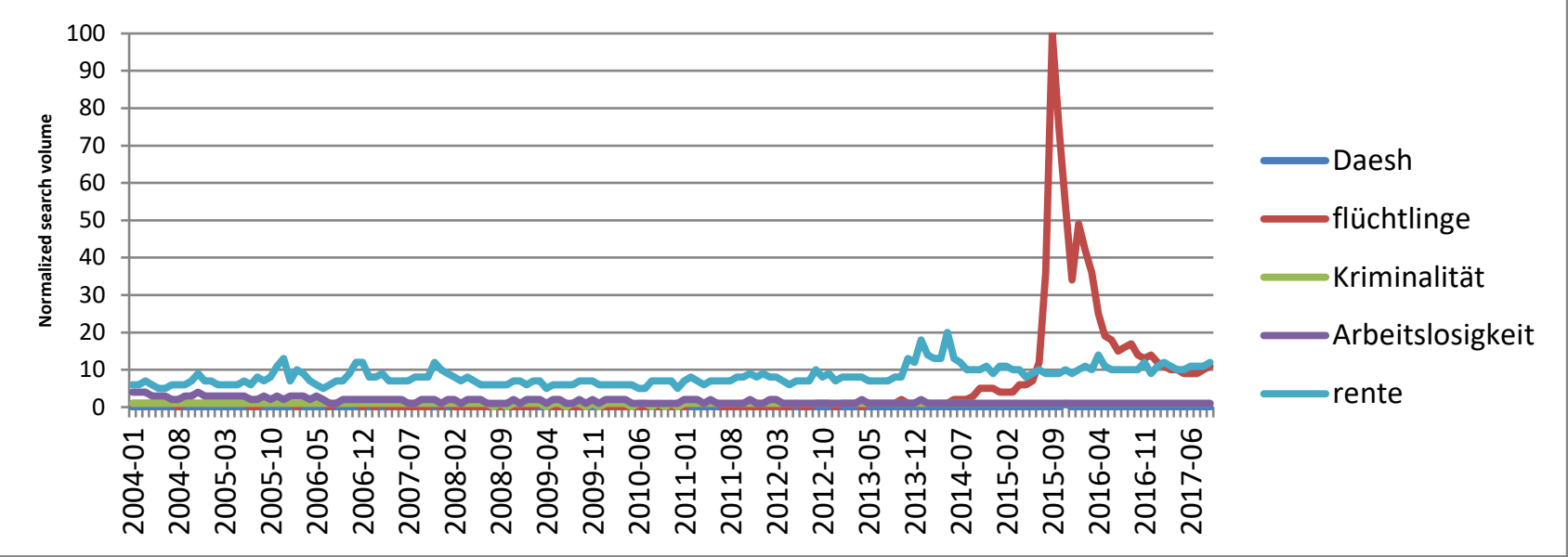

Figure 3.4: Google Trends, searches of ISIS, immigrants, crime, unemployment, and pensions in Italy, 2004-2017

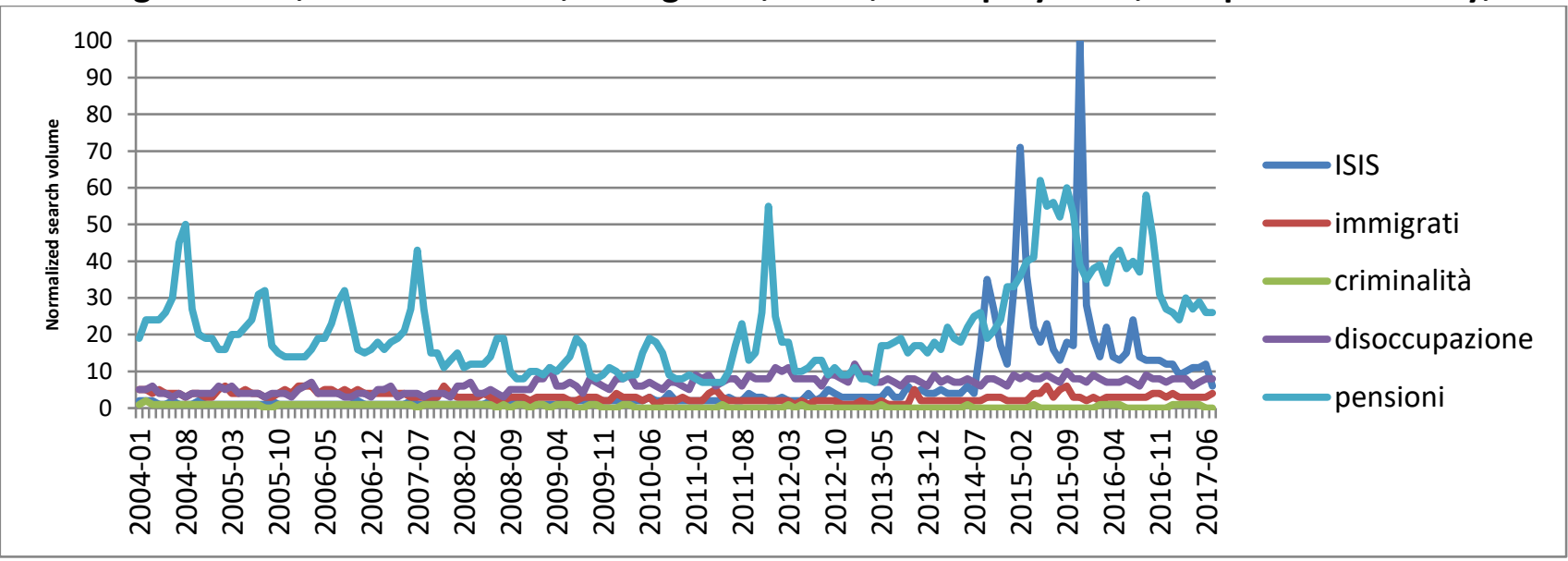


Figure 3.5: Google Trends, searches of ISIS, immigrants, crime, unemployment, and pensions in Sweden, 2004-2017

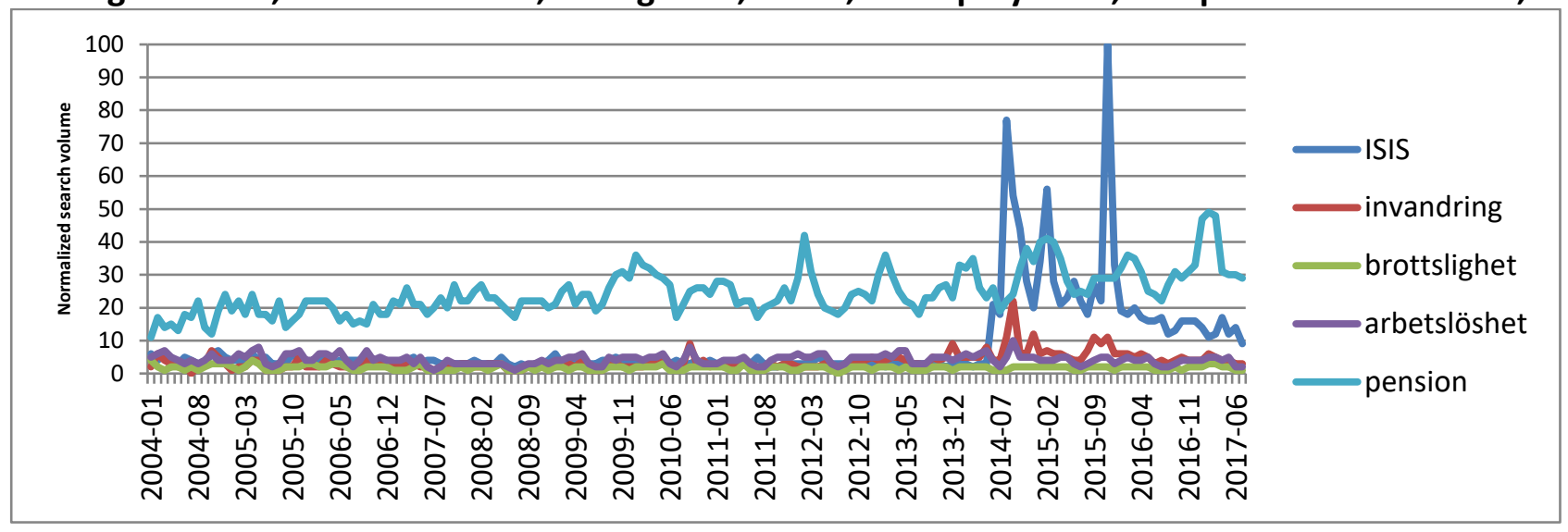

Figure 3.6: Google Trends, searches of ISIS, immigrants, crime, unemployment, and pensions in the United Kingdom, 20042017

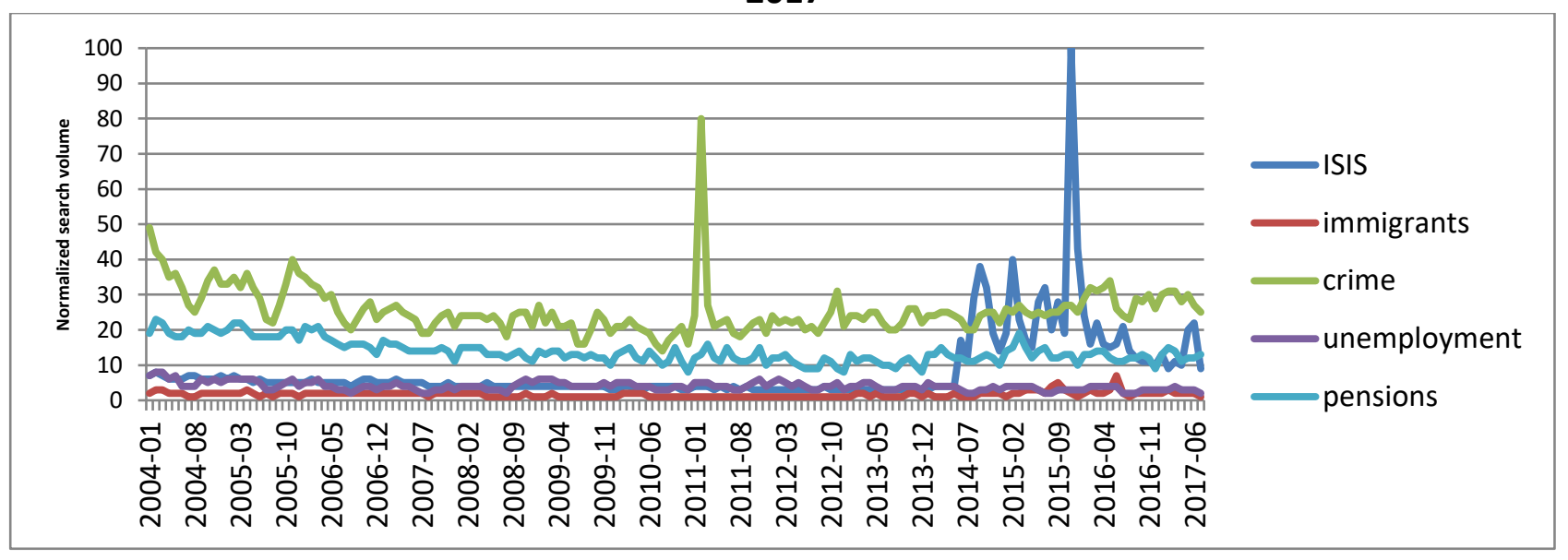


Figure 3.7: France: Google searches on pensions vs. Le Monde articles on pensions, 2004-2017

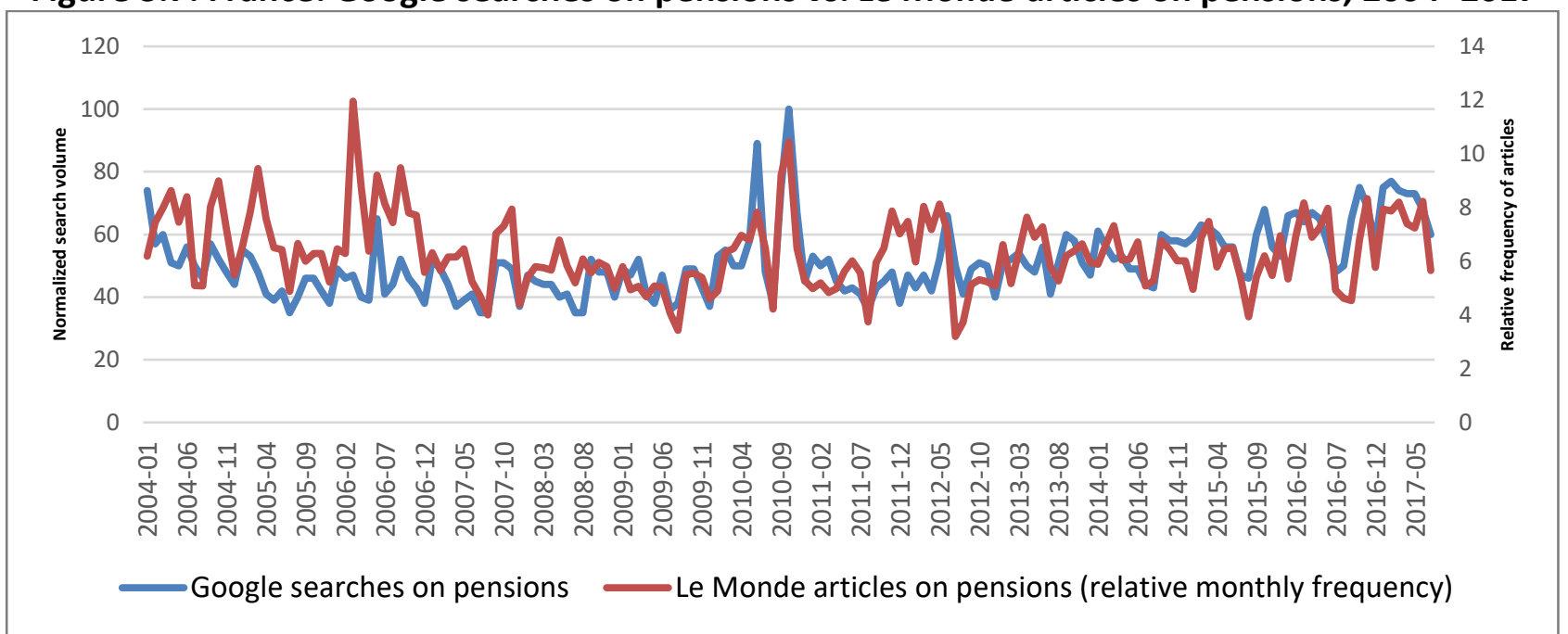

Figure 3.8: Germany: Google searches on pensions vs. FAZ articles on pensions, 2004-2017

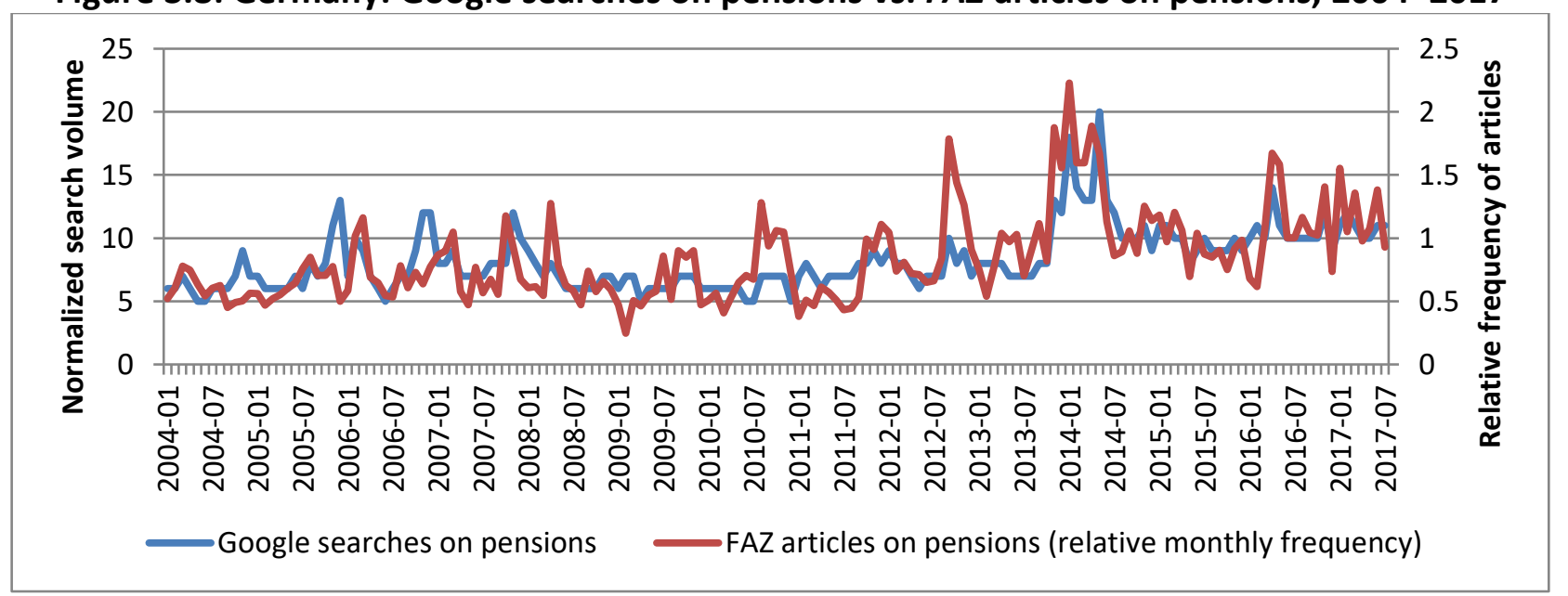


Figure 3.9: Italy: Google searches on pensions vs. Corriere della Sera articles on pensions, 2004-2017

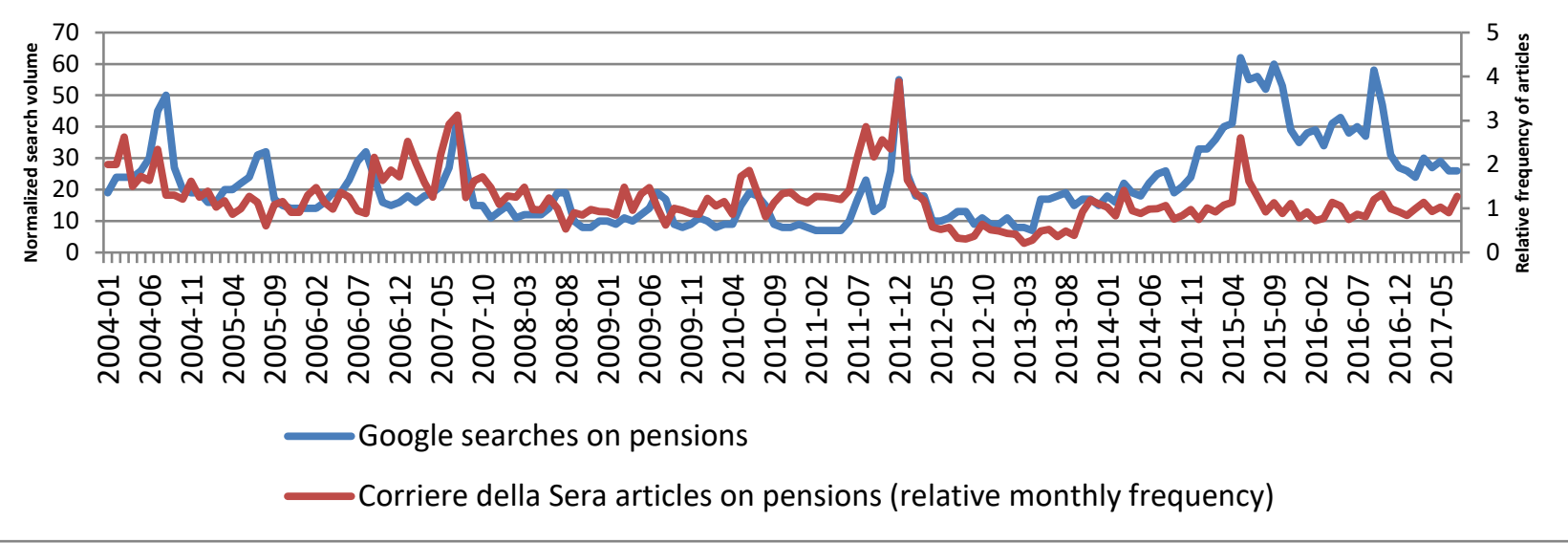

Figure 3.10: Sweden: Google searches on pensions vs. Svenska Dagbladet articles on pensions, 2004-2017

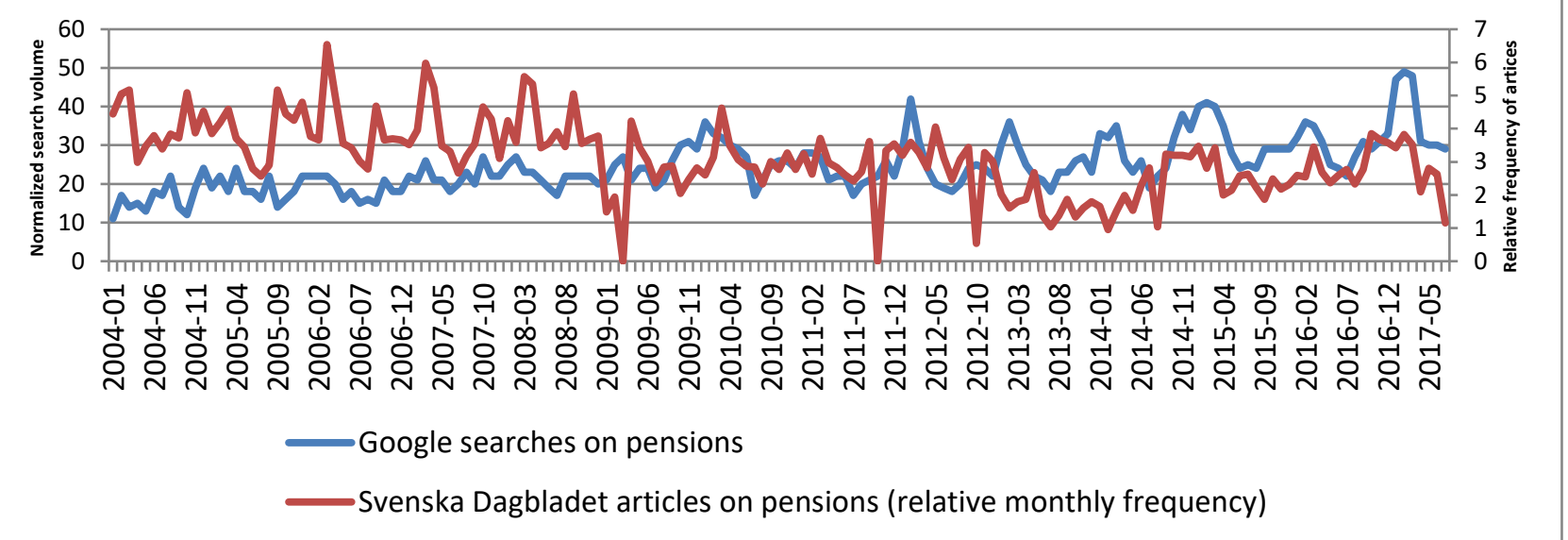


Figure 3.11: United Kingdom: Google searches on pensions vs. The Times articles on pensions, 2004-2017

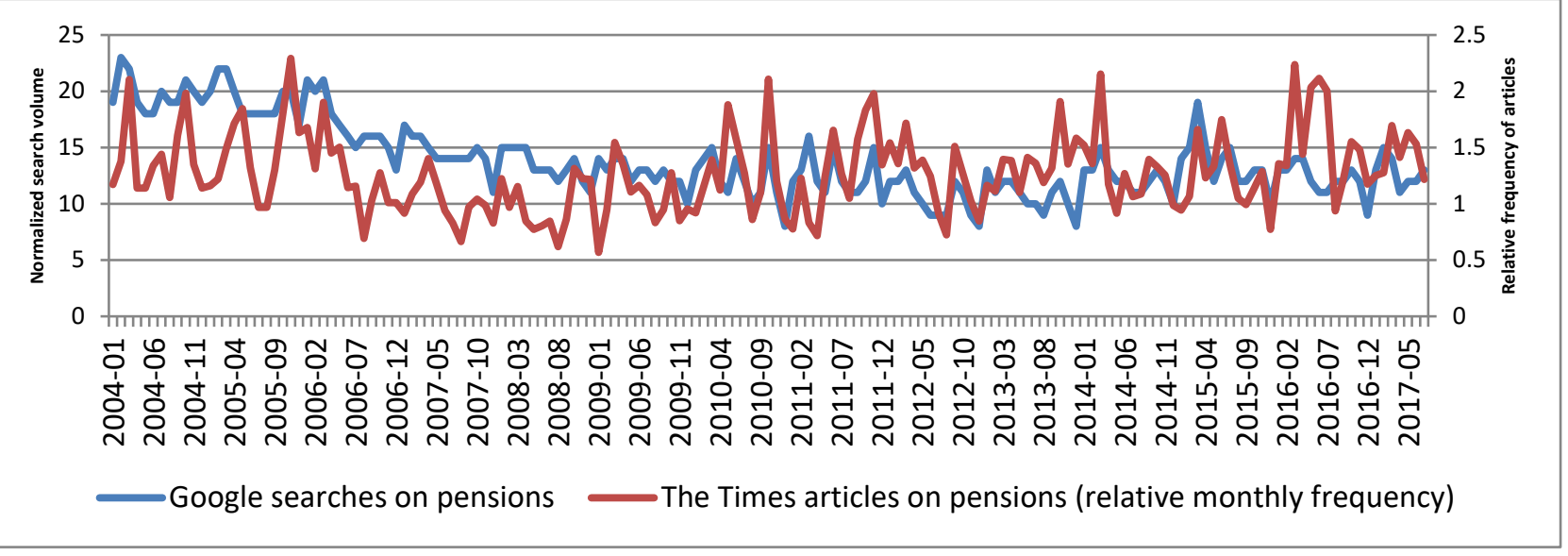


Figure 3.12: Histogram of articles about pensions in four Italian newspapers, November 2011 to February 2012

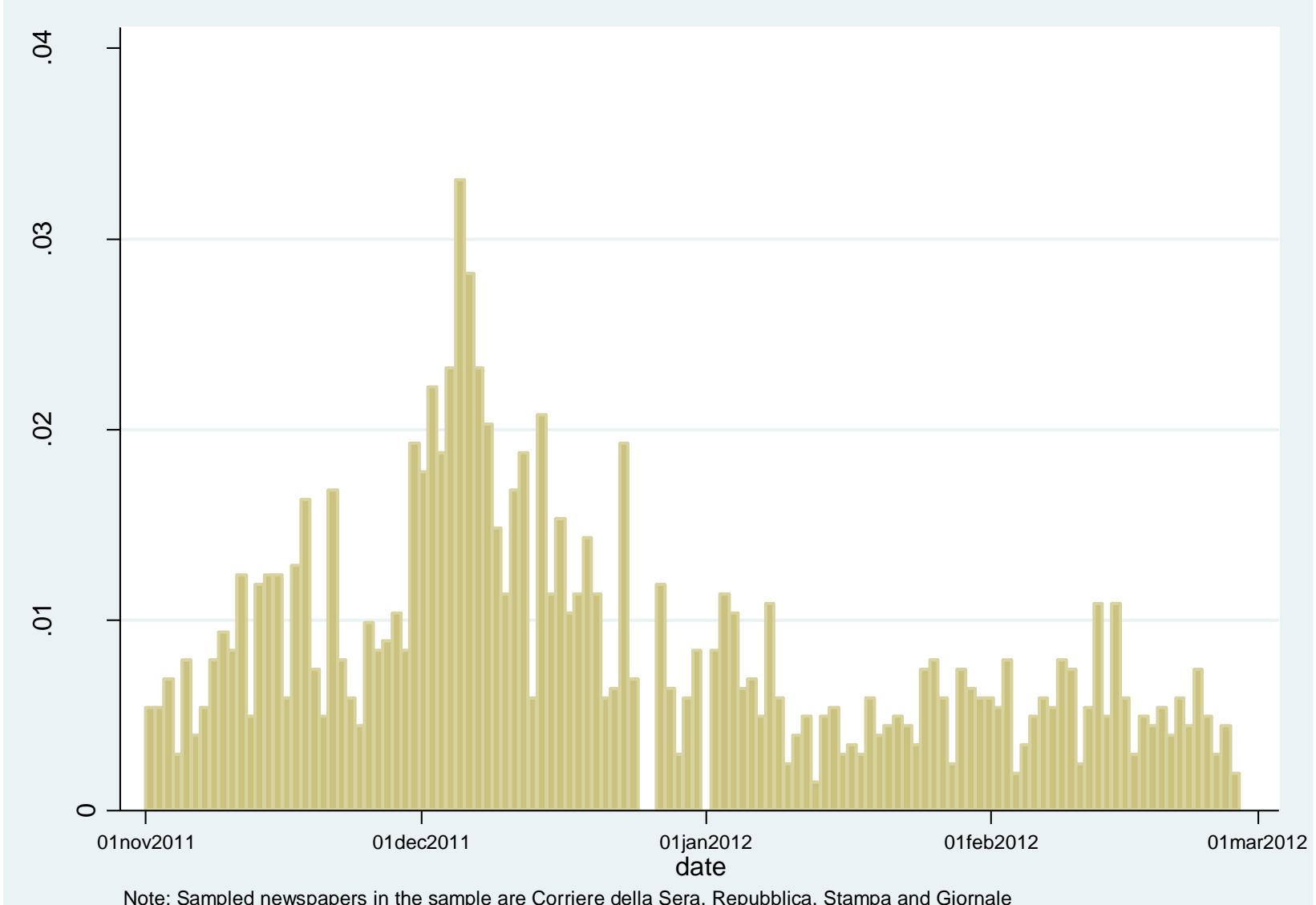

Note: Sampled newspapers in the sample are Corriere della Sera, Repubblica, Stampa and Giornale 
The next step is regression analysis of daily coverage data, where the dependent variables are the relative frequencies of pension articles that mention various concepts (Table 3.1) and political figures and countries (Table 3.2). The focus is on understanding how coverage varies before and after enactment of the reform (i.e., the day the Decree-Law was issued) and as a function of the newspaper under consideration. Thus each regression includes newspaper-specific fixed effects, a post-reform binary (dummy) variable, and a linear time trend. In order not to inflate the precision of the estimates, standard errors are clustered at the daily level. For each concept or figure, two different specifications are shown: the first one checks how the relative frequency of coverage changes after the reform unconditionally (i.e., it does not allow for newspaper-specific differences in those potential after-reform changes), while the second specification interacts the post-reform dummy variable with the newspaper-specific dummy variables.

As shown in Table 3.1, the words "reform," "spread" (between the returns of Italian versus German bonds), and "austerity" are cited significantly less after the reform, while no significant change is found for "growth" and "firms." On the other hand, the mention of "trade unions" significantly increases after the reform, which appears to be driven by the increase in coverage by Corriere and Repubblica. Comparing newspapers - taking Corriere as the excluded category - Repubblica and Giornale give significantly more coverage to the "spread" when dealing with pensions, while Giornale - and less robustly so Stampa devote less attention to "growth."

Table 3.2 shows that Europe is less significantly covered after the reform - albeit with a presence of an overall increasing trend. The same applies to Bersani (secretary of the Democratic Party, the main left-wing party in Italy), Berlusconi (leader of the main rightwing party and former prime minister), and German chancellor Angela Merkel. On the other hand, no significant change occurs in the coverage of Monti, Fornero, and Germany after the reform. Interestingly, the more extreme newspapers in the sample (i.e., Repubblica on the left and Giornale on the right) devote significantly more coverage to political figures visà-vis Corriere: this applies to Monti, Bersani, Berlusconi, and - to a lesser extent - Merkel. 
Table 3.1: Coverage of the Monti-Fornero pension reform on four national newspapers (Corriere, Repubblica, Stampa, Giornale), regression analysis

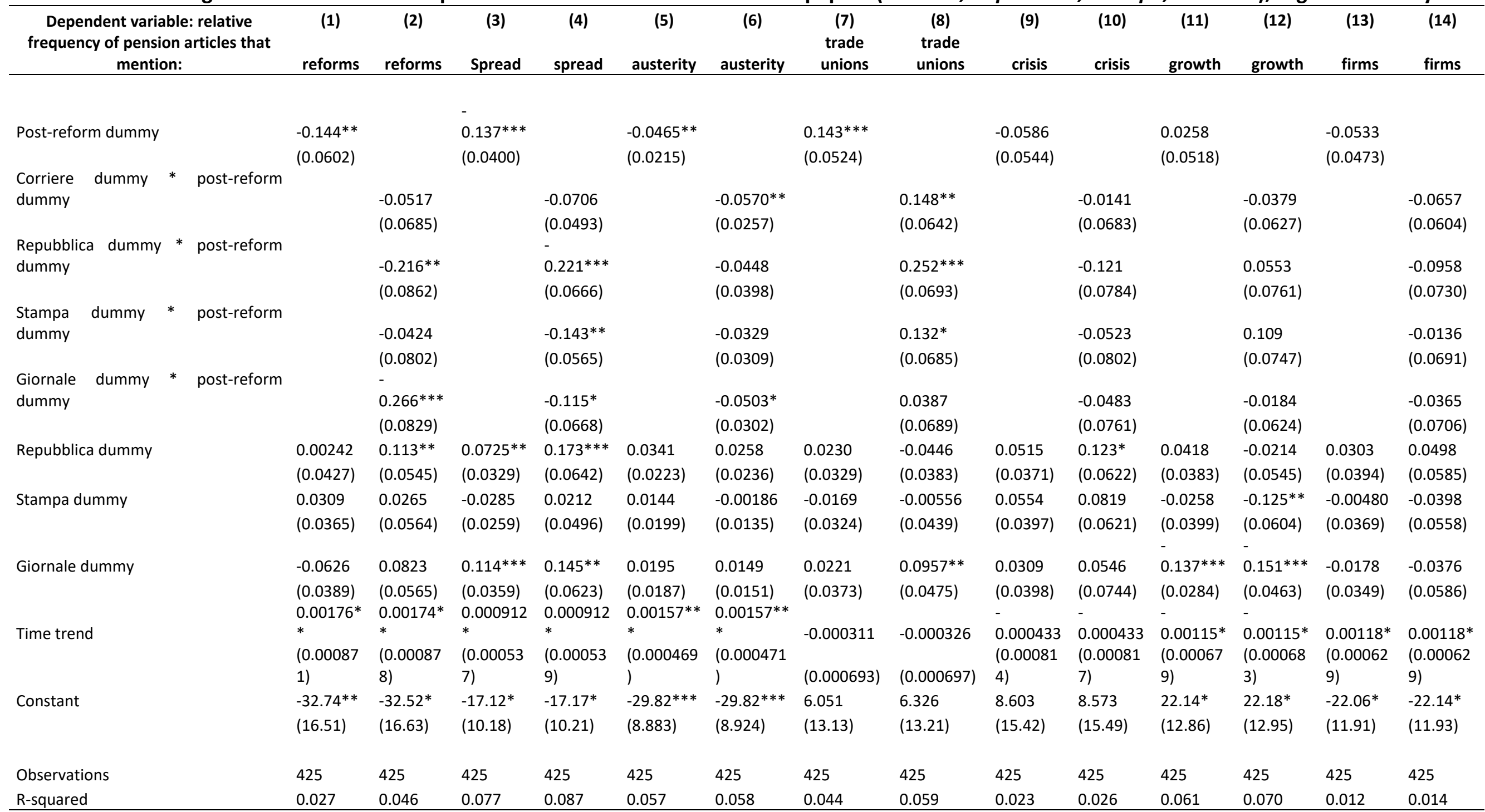

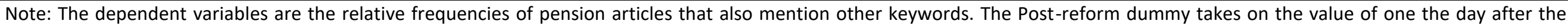

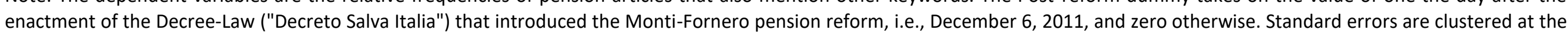
daily level and are shown below each coefficient. $* * * p<0.01, * * p<0.05, * p<0.1$ 
Table 3.2: Coverage of the Monti-Fornero pension reform on four national newspapers, regression analysis (cont.)

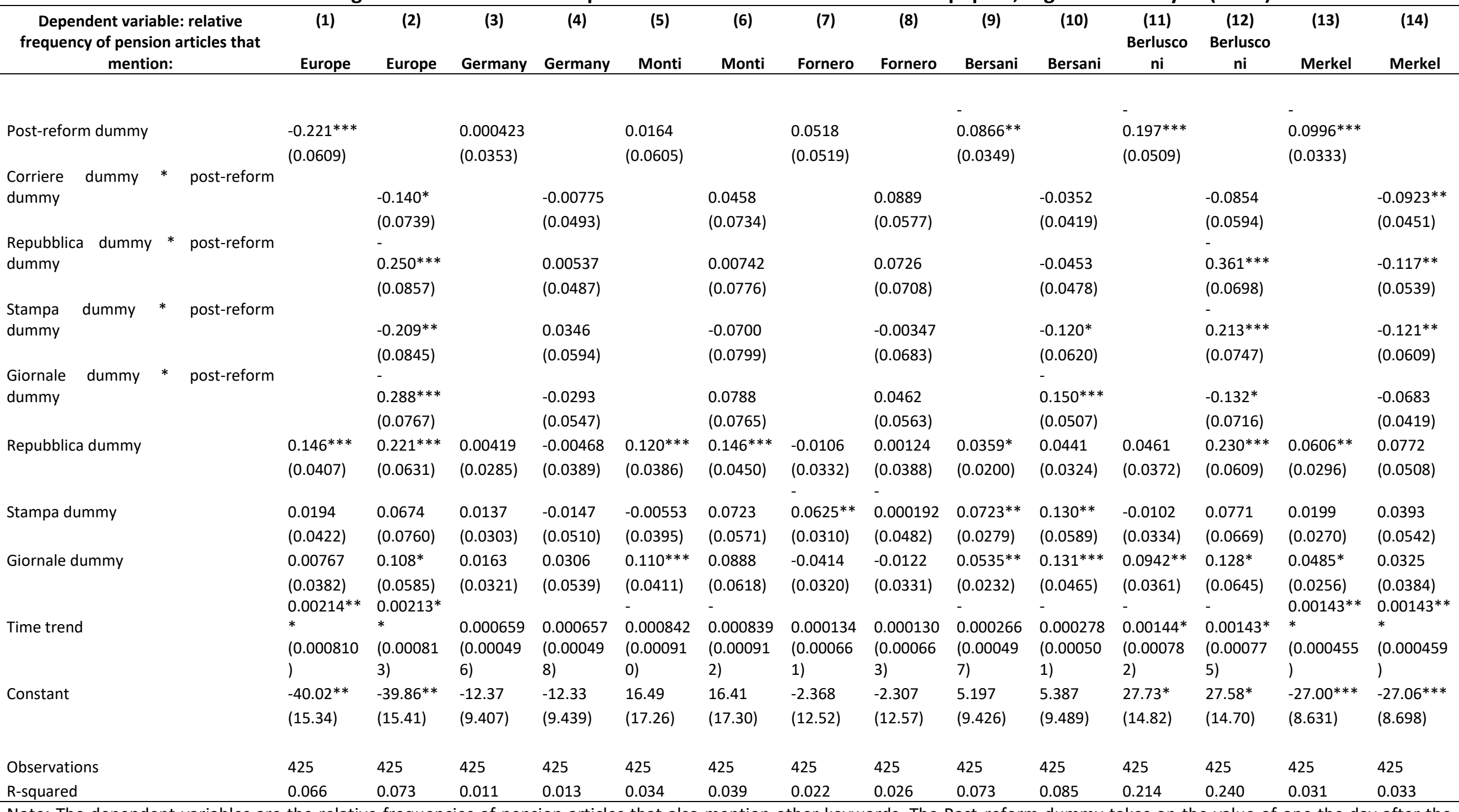

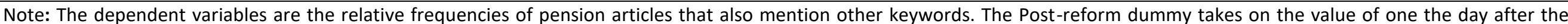

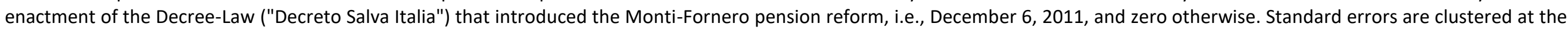
daily level and are shown below each coefficient. ${ }^{* * *} p<0.01,{ }^{* *} p<0.05,{ }^{*} p<0.1$ 
This is just a first attempt to analyze the way(s) media outlets cover a major pension reform in a time of crisis, but some preliminary conclusions can be drawn. First, the media frame that is centered around the need for the reform itself appears to be replaced after its enactment by more actor-centered coverage, where trade unions and their discontent get more media attention. Second, when covering pensions, more ideologically extreme newspapers give more coverage to political actors vis-à-vis more moderate outlets, but it is unclear whether this is a general pattern or is pension-specific.

\section{Financial literacy applied to pensions: What is "pension literacy"? Why is it important?}

\subsection{Why financial literacy is important for retirement: A selective review of the literature}

Welfare gains from individual choices depend on the efficiency of those choices, which in turn require, among other things, at least a basic understanding of their main elements and likely consequences, both in the short and the medium-long run. In the case of retirement saving, for example, even when it is compulsory and disguised under the payment of payroll taxes, understanding that "each dollar or euro of contribution counts" for the future pension benefit is crucial to make wiser and more farsighted choices, such as turning away from moonlight jobs, even if they appear more convenient in terms of net pay. ${ }^{14}$

To grasp the basic features of pensions, good information should thus complement widespread financial literacy. Illiteracy is instead associated with inattention to information, misinterpretation of pensions, and lack of knowledge of one's rights or, at the opposite, to claims of "acquired entitlements" that are hardly justifiable according to principles of social justice. This is, for example, the case for very generous - in terms of the difference between the amount (the present value) of benefits and contributions - DB pensions awarded to high income earners.

\footnotetext{
14 Of course, this is not always a choice for workers subject to binding financial constraints, in which case, the loss in pension wealth could be seen as a cost to overcome the liquidity constraint.
} 
Research has shown that widespread pension illiteracy can generate myopia, distortions, inconsistencies, and opportunistic conduct, such as a preference for early retirement not justified by hazardous working conditions or health flaws, and not supported by a parallel willingness "to pay for it" in terms of correspondingly reduced pension benefits (Calcagno, Coda Moscarola, and Fornero 2016). An excessively early retirement exposes workers to the risk of inadequate pension benefits at an older age, and the public budget to the moral pressure of adding resources so as not to abandon older people in need (the so-called "Samaritan's dilemma").

As mentioned in the introduction, most advanced economies witnessed a rather radical change in the retirement landscape in the last two to three decades. DC pensions ${ }^{15}$ have significantly expanded and are expected to expand more in the near future: thus, as already mentioned, individuals all over the world are (and will be) increasingly called to take greater responsibility to save, invest, and draw down their retirement wealth. DC pensions are normally more flexible than DB ones, implying more choices, even when - as is often the case - these are guided by appropriate design of default options. In addition, in most countries life expectancy is increasing, with people spending more years in retirement, as minimum retirement ages have not yet increased. And a longer retirement requires greater savings and resources to pay for the extra consumption and health care costs of these additional years (Kritzer and Smith 2016).

In this new pension landscape it is important to understand the extent to which individuals are equipped to make decisions and whether they are sufficiently knowledgeable about basic economic and financial notions and principles to make wise decisions, when required, and to plan for retirement. From this point of view, research found that those reporting that they are unable to plan for retirement and/or cannot carry out their retirement saving plans

\footnotetext{
15 Or, more generally, formulae characterized by a stronger correlation, at the individual level, between contributions paid and benefits received, and by an actuarial factor that takes into account the age of retirement and thus the different expected longevity at retirement.
} 
are also those who are least aware of fundamental economic concepts driving economic well-being over the lifecycle (Lusardi and Mitchell 2011). Many people lack key knowledge of financial concepts and fail to plan for retirement even when retirement is only 5-10 years off. This has important consequences, since 30-40 percent of wealth inequality can potentially be attributed to financial knowledge (Lusardi, Michaud, and Mitchell 2017).

Numeracy and inflation are fundamental concepts required for making saving decisions, and knowledge of risk diversification could help people make decisions about participating in a pension fund, as a way to combine the different risk-return combinations of an unfunded and a funded scheme. The knowledge of these simple concepts is strongly associated with successful retirement planning: those who cannot do a simple interest calculation or do not know about inflation and risk diversification are also much less likely to calculate how much they need to save for retirement (Lusardi and Mitchell 2008). The concept of compounded interest is especially important to know in the presence of NDC pension schemes: like most financial instruments, the rate of return in NDC plans works in a "compounded" way, generating returns from previous returns. Hence, in determining the final (notional) capital and thus the pension benefit, earlier contributions will have a higher weight than those paid at older ages.

Behrman et al. (2010) identified the impact of financial literacy and schooling on wealth accumulation and pension contribution patterns. Their estimates indicated that financial literacy is at least as important, if not more so, than schooling in explaining variation in household wealth and pension contributions. Van Rooij, Lusardi, and Alessie (2012) showed that financial sophistication boosts households' retirement planning behavior, thereby providing an important channel for the development of savings plans and creating instruments for self-control. Financially savvy employees are also most likely to participate in their DC plan (Clark, Lusardi, and Mitchell 2017). Lusardi, Mitchell, and Oggero (2017, 2018) also showed that financial literacy is among the factors reducing exposure to debt on the verge of retirement. 
Although much research on this topic is focused on the United States, a positive relationship between financial literacy and planning for retirement has been found in many other

countries such as France, Germany, Sweden, the Netherlands, Canada, New Zealand, Australia, Japan, and Chile, with some country-specific peculiarities (Arrondel, Debbich, and Savignac 2013; Bucher-Koenen and Lusardi 2011; Almenberg and Säve-Söderbergh 2011; Alessie, Van Rooij, and Lusardi 2011; Boisclair, Lusardi, and Michaud 2017; Crossan, Feslier, and Hurnand, 2011; Agnew, Bateman, and Thorp 2013; Sekita 2011; Gabarato Moure 2016). In the Italian pension landscape where private pensions are (very gradually) playing a greater role in ensuring old-age income, financial literacy increases the probability of saving for retirement through a private pension plan (Fornero and Monticone 2011).

\subsection{Basic understanding of NDC pensions as insurance that can accommodate redistribu- tion and make it more transparent}

Correct information and basic financial knowledge, at both the micro personalized and macro level, should contribute to citizens' understanding that pensions are not (or should not be considered) the result of the generosity of politicians, but of personal savings in the working period of the lifecycle, and of the sound functioning of the labor market, which is the source of income by which pensions in a PAYG system are paid. The pension system, as designed by the law, can translate this saving into adequate pension benefits with efficiency, equity, and sustainability, but it does not create new wealth per se. This social compact has an inherent insurance function, made explicit by the transformation, at retirement, of individuals' (notional) pension wealth into an income flow to be paid conditional on workers' (or their survivor's) existence. Citizens should also understand the "unfunded" nature of notional (PAYG) systems - i.e., the reliance on contributions paid by current workers to finance pensions, with additional funds possibly coming from the overall government budget, which in turn is financed by taxation, reduction of other expenditures, and/or additional deficit. Those additional funds should finance the redistributive part of the pension expenditure; i.e., the assistance component on top of the insurance one (the 
integration needed to reach the minimum pension level, or the contributions paid by the state in case of unemployment, maternity leave, or care activities).

The insurance feature embedded in the NDC system does allow for both solidarity and flexibility of retirement, concepts that people normally attach to a public pension system. Solidarity may come during the working life by contributions paid out of (progressive) general taxation for periods of unemployment/care/education and/or training. Flexible retirement is a "natural" good feature of NDC systems, in that it does not come at the expense of the young and future generations (as was the case with early retirement options under the DB method). Of course, in NDC systems as well, pensions are not mechanically determined only by an objective formula taken from "actuarial mathematics." In a public system, some redistribution will always be present and thus political choices will always have a role to play. NDC systems allow workers employed in specific jobs to retire earlier on the basis of (scientific) knowledge about their health and mortality conditions. People should be aware that an efficient pension system is certainly not unsuited to solidarity. On the contrary, efficiency and transparency of the NDC system make it more likely that its redistributive consequences are equitable and perceived as such, while lack of transparency is usually associated with (hidden) privileges and mounting disapproval rates for the system itself. Exceptions to the rule of the actuarial correspondence between contributions and benefits are possible (indeed, are due in a public system), but they should favor the unlucky members of society, not the lucky ones, generating intolerable privileges. As mentioned above, people should also recognize that an expensive pension system is financed mainly from contributions by workers/employers, implying a tradeoff between "generous" pensions and high (gross) labor costs, which discourages employment and might be also associated with lower net wages. It is important to convey these essential concepts in a few simple messages. This means that both politicians and the media should have a sufficient level of economic and financial literacy. 


\subsection{Pension literacy and the sustainability of pension systems/reforms}

Pension reforms affect people's lives and are often very unpopular, implying an electoral cost (par. 2.1). Financial literacy can help improve politics by providing antidotes to populist tendencies in difficult situations. Financial knowledge is not a panacea, but can provide a firm basis for higher social payoffs.

Reforms are meant not only to change laws but, more importantly, to change people's behavior. Their effectiveness crucially depends on the ability of citizens (i.e., public opinion) to recognize the importance, or in some cases the necessity, of reforms, their general design, and their "sense of direction." They have the nature of "social investments," requiring sacrifices today with the expectation of benefits tomorrow. The electorate's ability to understand essential economic concepts is a relevant element for the evaluation of the "electoral costs" of pension reforms. A recent paper (Fornero and Lo Prete 2019) shows that the electoral cost of a pension reform is significantly lower in countries where the level of financial literacy is higher. If entitlements are greater than contributions, and people understand that their pension "entitlements" are partly built on debt to be honored by future generations, they can be less hostile to pensions restructuring.

Again at the macro level, the "lump of labor fallacy" is still widespread. Jobs are too often regarded to be in a fixed number and early retirement is often considered, even at government level, as an easy way to create jobs for the young. This in turn might induce politicians to recommend generous early retirement options, to the detriment not only of the system's financial equilibrium but also of the adequacy of the benefits, with little or no gain in job creation for the young (Kalwij, Kapteyn, and de Vos 2010).

While information and financial literacy can intuitively be seen as complements, it has been objected that the cost-effectiveness of educational programs aimed at universal financial literacy is low relative to, for example, nudges. The increase of financial literacy (even on a very large scale) cannot, of course, be expected to be the successful answer to all economic and financial problems (the "silver bullet"). This paper asserts that this supposed contrast is 
wrong: financial literacy is not, of course, the only factor that would help to devise a good pension design and/or to increase the effectiveness of reforms. At the same time, the importance of a good design of choice options is not to be underrated. Behavioral "nudges" can encourage even financially literate people to make "wiser" choices: there is no need for one to exclude the other. Moreover, the process of trial and error as a substitute for financial knowledge might be extremely costly (more than investing in financial literacy). And a complementarity likely exists between financial literacy and reliance on experts: reliance on experts without diffusion of financial knowledge among the public might result in adverse selection and the troubling emergence of "charlatans." This phenomenon might be particularly intense - and worrisome - during periods with peak demand for experts and pundits, such as during severe economic and social crises, and in their long aftermath.

This is not to suggest that the combination of good information and financial literacy is a sufficient condition for the success of reforms. However, it is reasonable to argue that citizens who understand the basic principle of a reform should be less opposed to it when the reform is needed (and on the other hand, should be more opposed if the reform is meant to create differentiations and privileges). Since financial literacy can be improved by investing in education, governments may increase their citizens' awareness of what is involved in a reform by investing in specific educational programs for adults and basic financial education in school, and this may in turn help change the reform's electoral cost and future viability.

\section{Conclusions}

This paper revolved around the complementarity between information and financial literacy for an efficient and equitable functioning of NDC pension systems, and more generally of unfunded systems, at both the micro- and macroeconomic level. More specifically, it provided some new evidence - in the shape of stylized facts - about how public opinion in five European countries (France, Germany, Italy, Sweden, and the United Kingdom) is concerned with pensions, both in a cross-country perspective and in comparison with other 
policy issues. To do so, it exploited information on online searches, as provided by Google Trends, and matched these data with media coverage of pensions in traditional media (in this case, daily newspapers). It also looked at a specific case study - newspaper coverage of the 2011 Italian pension reform, introduced when Italy was on the edge of a financial crisis (Fornero 2013).

Much work on the topic of the complementarity between pension information and financial literacy is still to be done, both at the individual and macro level. First - besides developing a theoretical model to empirically test this relationship - a strong need exists for survey data providing evidence on what kind of information is provided about pensions, where people get this (formal and informal) information, and how they use it. Then one could check whether and how this use is influenced by the level of financial literacy, and whether the combination of good personalized information and basic financial knowledge effectively "produces" better retirement choices. To the authors' knowledge, this combination of data on the provision of information, their use, and individuals' basic financial knowledge is not available yet.

Second, a more comprehensive content analysis of newspaper articles and editorials and TV news about pensions should be performed, with a specific focus on the "quasi experiment" of pension reforms, to check whether and how the amount and tone of coverage change before and after reforms' actual enactment. A natural extension of this work would be to investigate how this coverage is correlated with the partisan bias of the media outlets under consideration (Gentzkow, Shapiro, and Stone 2015; Puglisi and Snyder 2015).

Finally, in the current era where social networks are playing an exponentially increasing role in the social, political, and media sphere, one could investigate the connection between coverage of pensions and pension reforms on traditional media (TV and newspapers, together with their online counterparts) and conversations on social network on the topic. A purpose of this analysis would be to investigate whether elite discourse on traditional media still happens to lead the conversation on social networks, or whether the opposite 
holds; i.e., online conversations take place first and influence arguments and proposals that are then featured on traditional media and possibly in the formal political arena (for example, in Parliament). 


\section{References}

Agnew, Julie R., Hazel Bateman, and Susan Thorp. 2013. "Financial Literacy and Retirement Planning in Australia." Numeracy 6(2): Article 7.

Alessie, Rob, Maarten Van Rooij, and Annamaria Lusardi. 2011. "Financial Literacy and Retirement Planning in the Netherlands." Journal of Pension Economics and Finance 10(4): 527-545.

Almenberg, Johan, and Jenny Säve-Söderbergh. 2011. "Financial Literacy and Retirement Planning in Sweden." Journal of Pension Economics and Finance 10(4): 585-598.

Arrondel, Luc, Majdi Debbich, and Frédérique Savignac. 2013. "Financial Literacy and Financial Planning in France." Numeracy 6(2): Article 8.

Behrman, Jere, Olivia S. Mitchell, Cindy Soo, and David Bravo. 2010. "Financial Literacy, Schooling, and Wealth Accumulation." NBER Working Paper No. 16452, NBER, Cambridge, MA.

Boisclair, David, Annamaria Lusardi, and Pierre-Carl Michaud. 2017. "Financial Literacy and Retirement Planning in Canada." Journal of Pension Economics and Finance 16(3): 277-296.

Bucher-Koenen, Tabea, and Annamaria Lusardi. 2011. "Financial Literacy and Retirement Planning in Germany" Journal of Pension Economics and Finance 10(4): 565-584.

Buti, Marco, Alessandro Turrini, Paul Van den Noord, and Pietro Biroli. 2008. "Defying the "Juncker Curse": Can Reformist Governments Be Re-elected?" European Economic Papers 3241, May.

Calcagno, Riccardo, Flavia Coda Moscarola, and Elsa Fornero. 2017. "Too Busy to Stay at Work. How Willing Are Italian Workers 'To Pay' for Earlier Retirement?" Economics Bulletin 37(3): 1694-1707. 
Chlon-Dominczak, Agnieszka. 2009. "Retirement Behaviour in Poland and the Potential Impact of Pension System Changes." ENEPRI Research Report No. 61/January, Brussels.

Clark, Robert, Annamaria Lusardi, and Olivia S. Mitchell. 2017. "Employee Financial Literacy and Retirement Plan Behavior: A Case Study." Economic Inquiry 55(1): 248-259.

Crossan, Diana, David Feslier, and Roger Hurnard. 2011. "Financial Literacy and Retirement Planning in New Zealand." Journal of Pension Economics and Finance 10(4): 619-635.

Fornero, Elsa. 2013. "Reforming Labor Markets. Reflections of an Economist Who (Unexpectedly) Became the Italian Minister of Labor." IZA Journal of European Labor Studies: 2-20.

. 2014. "Reform, Inform and Educate. The New Paradigm for Pension Systems' Sustainability." In The Future of Welfare in a Global Europe, ed. Bernd Marin, Chapter 8, pp. 297-324.

Fornero, Elsa, and Chiara Monticone. 2011. “Financial Literacy and Pension Plan Participation in Italy." Journal of Pension Economics and Finance 10(4): 547-564.

Fornero, Elsa, and Anna Lo Prete. 2019. "Voting in the Aftermath of a Pension Reform: The Role of Financial Literacy." Journal of Pension Economics and Finance 19(1): 1-30.

Fox, Louise, and Edward Palmer. 1999. "Latvian Pension Reform." Social Protection Discussion Paper No. 9922, World Bank, Washington, DC.

Gallup. 2015. "In Depth: Topics A to Z. Social Security." Available at: http://www.gallup.com/poll/1693/social-security.aspx

Garabato Moure, Natalia. 2016. "Financial Literacy and Retirement Planning in Chile." Journal of Pension Economics and Finance 15(2): 203-223. 
Gentzkow, Matthew, Jesse M. Shapiro, and Daniel F. Stone. 2015. "Media Bias in the Marketplace: Theory." In Handbook of Media Economics, ed. Simon Anderson, Joel Waldfogel, and David Stromberg, Volume 1B, pp. 623-645. North Holland.

Istat. 2016. "The Knowledge of Economic Data by Italian Consumers." Available at: http://www.istat.it/en/archive/189746

Kalwij, Adriaan, Arie Kapteyn, and Klaas de Vos. 2010. "Retirement of Older Workers and Employment of the Young." De Economist 158(4): 341-359.

Kritzer, Barbara E., and Barbara A. Smith. 2016. "Public Pension Statements in Selected Countries: A Comparison." Social Security Bulletin 76(1).

Lusardi, Annamaria, and Olivia S. Mitchell. 2008. “Planning and Financial Literacy. How Do Women Fare?" American Economic Review 98(2): 413-417.

. 2011. "Financial Literacy and Planning: Implications for Retirement Wellbeing." In Financial Literacy. Implications for Retirement Security and the Financial Marketplace, ed. Annamaria Lusardi and Olivia S. Mitchell, pp. 17-39. Oxford University Press.

Lusardi, Annamaria, Pierre-Carl Michaud, and Olivia S. Mitchell. 2017. “Optimal Financial Knowledge and Wealth Inequality." Journal of Political Economy 125(2): 431-477.

Lusardi, Annamaria, Olivia S. Mitchell, and Noemi Oggero. 2017. "Debt and Financial Vulnerability on the Verge of Retirement." NBER Working Paper No. 23664, Cambridge, MA. . 2018. "The Changing Face of Debt and Financial Fragility at Older Ages." American Economic Association Papers and Proceedings 108: 407-411.

Mastrobuoni, Giovanni. 2011. "The Role of Information for Retirement Behavior: Evidence Based on the Stepwise Introduction of the Social Security Statement." Journal of Public Economics 95(7-8): 913-925. 
Puglisi, Riccardo, and James M. Snyder, Jr. 2015. "Empirical Studies of Media Bias." In Handbook of Media Economics, ed. Simon Anderson, Joel Waldfogel, and David Strömberg, Volume 1B, pp. 647-667. North Holland.

Sekita, Shizuka. 2011. "Financial Literacy and Retirement Planning in Japan." Journal of Pension Economics and Finance 10(4): 637-656.

Sundén, Annika. 2009. "Learning from the Experience of Sweden: The Role of Information and Education in Pension Reform." In Overcoming the Saving Slump, ed. Annamaria Lusardi, pp. 324-344. University of Chicago Press.

The Economist. March 15, 2007. "The Quest for Prosperity." Available at http://www.economist.com/node/8808044.

Van Rooij, Maarten, Annamaria Lusardi, and Rob Alessie. 2012. "Financial Literacy, Retirement Planning, and Household Wealth." Economic Journal 122: 449-478. 


\section{Social Protection \& Jobs Discussion Paper Series Titles 2017-2019}

No. $\quad \underline{\text { Title }}$

1929 Developing Coherent Pension Systems: Design Issues for Private Pension Supplements to NDC Schemes by William Price

April 2019

Pensions in a Globalizing World: How Do (N)DC and (N)DB Schemes Fare and Compare on Portability and Taxation?

by Bernd Genser and Robert Holzmann

April 2019

1927 The Politics of NDC Pension Scheme Diffusion: Constraints and Drivers

by Igor Guardiancich, R. Kent Weaver, Gustavo Demarco, and Mark C. Dorfman

April 2019

1926 Setting Up a Communication Package for the Italian NDC

by Tito Boeri, Maria Cozzolino, and Edoardo Di Porto

April 2019

1925 Sweden's Fifteen Years of Communication Efforts

by María del Carmen Boado-Penas, Ole Settergren, Erland Ekheden, and Poontavika Naka

April 2019

1924 Information and Financial Literacy for Socially Sustainable NDC Pension Schemes

by Elsa Fornero, Noemi Oggero, and Riccardo Puglisi

April 2019

1923 Communicating NEST Pensions for "New" DC Savers in the United Kingdom

by Will Sandbrook and Ranila Ravi-Burslem

April 2019

Harnessing a Young Nation's Demographic Dividends through a Universal NDC Pension Scheme: A Case

Study of Tanzania

by Bo Larsson, Vincent Leyaro, and Edward Palmer

April 2019

1921 The Notional and the Real in China's Pension Reforms

by Bei Lu, John Piggott, and Bingwen Zheng

April 2019

1920 Administrative Requirements and Prospects for Universal NDCs in Emerging Economies

by Robert Palacios

April 2019

1919

Bridging Partner Lifecycle Earnings and Pension Gaps by Sharing NDC Accounts

by Anna Klerby, Bo Larsson, and Edward Palmer

April 2019 
by Agnieszka Chłoń-Domińczak, Marek Góra, Irena E. Kotowska, Iga Magda, Anna Ruzik-Sierdzińska, and Paweł Strzelecki

April 2019

1917 Drivers of the Gender Gap in Pensions: Evidence from EU-SILC and the OECD Pension Model by Maciej Lis and Boele Bonthuis

April 2019

1916 Gender and Family: Conceptual Overview

by Nicholas Barr

April 2019

1915 Labor Market Participation and Postponed Retirement in Central and Eastern Europe by Robert I. Gal and Márta Radó

April 2019

$1914 \quad$ NDC Schemes and the Labor Market: Issues and Options by Robert Holzmann, David Robalino, and Hernan Winkler April 2019

1913 NDC Schemes and Heterogeneity in Longevity: Proposals for Redesign by Robert Holzmann, Jennifer Alonso-García, Heloise Labit-Hardy, and Andrés M. Villegas April 2019

1912 Annuities in (N)DC Pension Schemes: Design, Heterogeneity, and Estimation Issues by Edward Palmer and Yuwei Zhao de Gosson de Varennes April 2019

1911 Overview on Heterogeneity in Longevity and Pension Schemes by Ron Lee and Miguel Sanchez-Romero

April 2019

1910 Chile's Solidarity Pillar: A Benchmark for Adjoining Zero Pillar with DC Schemes by Eduardo Fajnzylber

April 2019

1909 Sweden: Adjoining the Guarantee Pension with NDC by Kenneth Nelson, Rense Nieuwenhuis, and Susanne Alm April 2019

1908 The ABCs of NDCs by Robert Holzmann April 2019

1907 NDC: The Generic Old-Age Pension Scheme by Marek Góra and Edward Palmer April 2019

1906 The Greek Pension Reforms: Crises and NDC Attempts Awaiting Completion by Milton Nektarios and Platon Tinios April 2019 
1904 The Polish NDC Scheme: Success in the Face of Adversity by Sonia Buchholtz, Agnieszka Chłoń-Domińczak, and Marek Góra April 2019

1903 The Italian NDC Scheme: Evolution and Remaining Potholes by Sandro Gronchi, Sergio Nisticò, and Mirko Bevilacqua April 2019

The Latvian NDC Scheme: Success Under a Decreasing Labor Force by Edward Palmer and Sandra Stabina April 2019

The Swedish NDC Scheme: Success on Track with Room for Reflection by Edward Palmer and Bo Könberg April 2019

Rapid Social Registry Assessment: Malawi's Unified Beneficiary Registry (UBR) by Kathy Lindert, Colin Andrews, Chipo Msowoya, Boban Varghese Paul, Elijah Chirwa, and Anita Mittal, November 2018 by Ugo Gentilini, Sarah Laughton and Clare O’Brien, November 2018 by Afrah Alawi Al-Ahmadi and Samantha de Silva, July 2018

1705 Aging and Long-Term Care Systems: A Review of Finance and Governance Arrangements in Europe, North America and Asia-Pacific

by Laurie Joshua, November 2017

1704 Social Registries for Social Assistance and Beyond: A Guidance Note \& Assessment Tool by Phillippe Leite, Tina George, Changqing Sun, Theresa Jones and Kathy Lindert, July 1027

Social Citizenship for Older Persons? Measuring the Social Quality of Social Pensions in the Global South and Explaining Their Spread by Tobias Böger and Lutz Leisering, July 2017

The Impacts of Cash Transfers on Women's Empowerment: Learning from Pakistan's BISP Program by Kate Ambler and Alan de Brauw, February 2017

Social Protection and Humanitarian Assistance Nexus for Disaster Response: Lessons Learnt from Fiji's Tropical Cyclone Winston by Aisha Mansur, Jesse Doyle, and Oleksiy Ivaschenko, February 2017

To view Social Protection \& Jobs Discussion Papers published prior to 2017, please visit www.worldbank.org/sp. 


\section{ABSTRACT}

This paper is centered on the complementary roles played by pension communication/information and financial literacy for a sustainable and equitable nonfinancial defined contribution (NDC) system at both the micro and macro socioeconomic level. The paper presents new evidence on: (i) the concern of public opinion about pensions in five European countries (France, Germany, Italy, Sweden, and the United Kingdom), as approximated by Google Trends data; (ii) the relationship between measures of online search volume and coverage by traditional media (i.e., national newspapers); and (iii) the volume and framing of newspaper coverage for a specific reform (i.e., the 20111 Italian reform). On the demand (users) side, the paper considers pension literacy as an element to increase the effectiveness of reforms.

\section{ABOUT THIS SERIES}

Social Protection \& Jobs Discussion Papers are published to communicate the results of The World Bank's work to the development community with the least possible delay. This paper therefore has not been prepared in accordance with the procedures appropriate for formally edited texts.

For more information, please contact the Social Protection Advisory Service, the World Bank, 1818 H Street, N.W., Room G7-803, Washington, DC 20433, USA. Telephone: +1 (202) 458 5267, Fax: +1 (202) 614 0471, E-mail: socialprotection@worldbank.org or visit us on-line at www.worldbank.org/sp. 